\title{
Evaluation of mutagenicity associated with Escherichia coli inactivation in UV-treated orange juice
}

\author{
Maria Rodríguez ${ }^{\mathrm{a}}$, Juan Oteizab ${ }^{\mathrm{b}}$, Leda Giannuzzi ${ }^{\mathrm{a}}$ and Noemi Zaritzky (iD) ${ }^{\mathrm{a}, \mathrm{c}}$

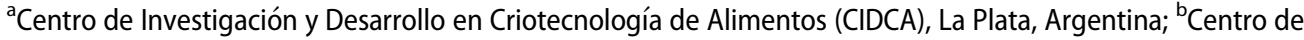

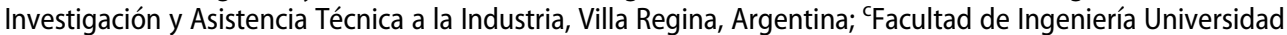 \\ Nacional de La Plata, La Plata, Argentina
}

\begin{abstract}
UV radiation is an alternative technology for the elimination of pathogenic micro-organisms in liquid food. The objectives of this work were to investigate mutagenesis using the Ames test in : (1) fresh squeezed orange juice submitted to UV radiation doses required to achieve 5 and $10 \log _{10}$ reductions of different strains of Escherichia coli serotype 0157:H7 at two temperatures, and (2) commercial pasteurized orange juice submitted to thermal treatment.

Two histidine-auxotrophic strains, Salmonella Typhimurium TA98 and TA97a, were used in the Ames test with and without metabolic activation.

In commercial pasteurized orange juices, mutagenesis was not observed with $S$. Typhimurium TA98 strain with and without metabolic activation, but high mutagenic effect was observed using TA97a with metabolic activation.

UV radiation did not affect the stability of ascorbic acid in aqueous solution. However, degradation of ascorbic acid was observed when UV treatment was performed on squeezed orange juice, following first order kinetics.

UV treatment required to achieve $5 \log _{10}$ reductions $\left(1.5 \mathrm{~J} / \mathrm{cm}^{2}\right)$ did not show a mutagenic effect with and without metabolic activation using the tested strains, but a higher UV radiation dose necessary to produce $10 \log _{10}$ reductions $\left(3.0 \mathrm{~J} / \mathrm{cm}^{2}\right)$ showed mutagenicity with metabolic activation.
\end{abstract}

\section{ARTICLE HISTORY}

Received 10 November 2015

Accepted 12 April 2016

\section{KEYWORDS}

Mutagenicity; UV radiation; orange juice; Ames test; ascorbic acid

\section{Introduction}

Fresh and pasteurized fruit juices are widely consumed due to their nutritional properties and the content of organic acids, flavanones, hydroxycinnamic acid, and sugars.

Global orange juice production for 2015/16 is estimated to be around 1.8 million metric tons and the main producing countries are Brazil, the United States, Mexico, the European Union, China, South Africa, and Australia, based on the information provided by the US Department of Agriculture (USDA 2016). Orange juice is the most appreciated 
and consumed juice because of its taste and high ascorbic acid (AA) concentration. Moreover, it is the predominant juice manufactured by the industry worldwide (López-Gomez, Ros-Chumillas, and Belisario-Sánches 2010).

Fruit juices are spoiled primarily due to proliferation of acid tolerant and osmophilic microflora. There is also the risk of food-borne microbial infections which are associated with the consumption of fruit juices (Aneja et al. 2014). Conventional thermal pasteurization is a known technique to reduce the number of pathogens such as Escherichia coli serotype O157:H7, Salmonella sp., Listeria monocytogenes, and Cryptosporidium parvum in juices (Tandon et al. 2003). Pasteurization of fruit juices is effective against pathogenic and several spoilage micro-organisms. However, sensory and nutritional properties could be affected. The Food and Drug Administration (FDA) has recommended $5 \log _{10}$ reductions of infection pathogens in a fruit juice, which can be achieved by pasteurization at 90-95 ${ }^{\circ} \mathrm{C}$ for $4-10$ seconds (Aneja et al. 2014). Considering that thermal pasteurization could damage nutritional and physicochemical properties of fruit juices, non-thermal methods become an alternative. Non-thermal treatments have been proposed to reduce the level of micro-organisms, maintaining at the same time the aroma and flavor components (Rupasinghe and $\mathrm{Yu}$ 2012). UV radiation treatment is an attractive technology for the elimination of pathogenic micro-organisms in liquid food (Torkamani and Niakousari 2011).

Due to E. coli outbreaks linked to unpasteurized apple cider and contaminated fruit juices, FDA (2012) issued a rule in 2001 requiring most juice producers to follow hazard analysis and critical control points with ultraviolet light (UV-C) treatment as one of the acceptable methods. The efficacy of UV radiation to control pathogens in apple cider has been the focus of different studies (Wright et al. 2000; Hanes et al. 2002; Basaran et al. 2004, Choudhary and Bandla 2012).

Choi and Nielsen (2005) demonstrated that UV pasteurized apple cider was superior in color and overall sensory scores compared to thermally pasteurized apple cider. The CiderSure 3500 UV light unit (FPE Inc., Rochester, NY, USA) has been developed to treat apple juice/cider with UV light to reduce the levels of microbial pathogens in juice products. The objective of CiderSure 3500 was specifically to reduce the levels of E. coli serotype 0157:H7, an organism linked to various food-borne outbreaks caused by the consumption of contaminated fresh apple juice/cider. Studies using apple cider that utilized the CiderSure apparatus confirmed the ability of this equipment to achieve a 5-log reduction of Cryptosporidium parvum and E. coli (Hanes et al. 2002; Basaran et al. 2004).

Koutchma et al. (2004) studied the efficacy of UV light on the destruction of E. coli K12 in apple juice using laminar and turbulent flow UV reactors. FDA (2013) expressed a growing interest in using UV light to treat fruit juices, especially apple juice and cider (Sastry, Datta, and Worobo 2000). The performance of UV radiation depends on the absorptivity and turbidity of the juices. According to Koutchma et al. (2004), clear apple juice has low absorptivity, with an absorption coefficient of $11 \mathrm{~cm}^{-1}$, whereas orange juice can have absorption coefficients close to $100 \mathrm{~cm}^{-1}$.

Koutchma, Forney, and Moraru (2009) reported that UV light processing can be a viable non-thermal alternative for eliminating or reducing the levels of undesirable microorganisms in food and beverages. The germicidal properties of UV radiation are due to the DNA absorption of the UV light, causing crosslinking between neighboring pyrimidine nucleoside bases (thymine and cytosine) in the same DNA strand (FDA 2013). The 
amount of crosslinking is proportional to the intensity of UV exposure. The level of mutations that can be reversed depends on the UV repair system present in the target microorganism. Once the threshold of crosslinking has been exceeded, the number of crosslinks is beyond repair and cell death occurs (Miller et al. 1999)., Photoreactivation, a repair mechanism that is enhanced by visible light in the blue spectral range, may occur with some bacterial cells. Cells show greater resistance to UV radiation (photoreactivated) than non-reactivated cells (FDA 2013). For this reason, higher radiant exposures are required to ensure effective inactivation of micro-organisms avoiding the photoreactivation process. UV light can adversely affect food by generating free radicals in products by a wide variety of organic photochemical reactions. The effect of UV on the potential formation of chemical compounds in foods that may present a health threat should be evaluated to determine whether there are toxicological or chemical safety concerns associated with products that have undergone UV treatment.

Oteiza et al. (2005) worked with two E. coli strains (non-pathogenic ATCC 25922, and pathogenic O157:H7 EDL 933) that were inoculated in stirred thin films of commercial pasteurized orange juice, submitted to UV radiation at 4 and $20{ }^{\circ} \mathrm{C}$. These authors determined UV radiation doses needed to reduce the microbial population in a log cycle. Oteiza, Giannuzzi, and Zaritzky (2010) demonstrated that in fresh squeezed orange juice, the presence of natural microbial flora (acid lactic bacteria, thermo-acidophilic bacteria, molds, and yeasts) decreased the performance of UV radiation on E. coli inactivation. UV-absorbing components and micro-organisms, like yeasts, increased the necessary UV dose to inactivate the target micro-organisms. These authors reported that in fresh squeezed orange juice, the UV radiation dose required to reach 5-log reduction, for the most UV resistant $E$. coli strain, and the maximum yeast concentration ranged between 1.5 and $3.0 \mathrm{~J} / \mathrm{cm}^{2}$.

UV light interacts with components of the juices and could generate carcinogenic or mutagenic by-products, but the literature on this subject is scarce.

A number of different "short-term tests" have been developed to investigate the genotoxic properties of chemicals in food and the environment. One of the best validated tests is the Ames test, which explores the capability of a certain compound or mixture to induce mutations in specific S. Typhimurium his ${ }^{-}$strains (Maron and Ames 1983). The Ames Salmonella/microsome mutagenicity assay (Ames test) is a short-term bacterial reverse mutation test specifically designed to detect a wide range of chemical substances that can produce genetic damage leading to gene mutations.

Reyns, Diels, and Michiels (2004) studied the inactivation of E. coli, S. Typhimurium, and Listeria innocua $\left(10^{8} \mathrm{CFU} / \mathrm{mL}\right)$ working with a non-thermal treatment, such as high pulsed electric fields (PEF) applied to buffer systems and grape juice. They concluded that in the Ames mutagenicity test using S. Typhimurium mutant strains TA102 and TA104, PEF treated grape juice showed mutagenicity, causing a dose-dependent increase in his ${ }^{-}$ reversion frequency compared to untreated juice.

Mazaki, Ishii, and Uyeta (1982) examined hydrolyzates of citrus fruit juices for mutagenicity, attributing it to flavonols such as quercetin. Ekasari, Jongen, and Pilnik (1986), working with freshly pressed orange juice heated for $30 \mathrm{~min}$ at $93{ }^{\circ} \mathrm{C}$ and with commercial juices, reported heat induced mutagenicity due to Maillard products. Friedman, Wilson, and Ziderman (1990) and Franke et al. (2004) studied mutagenicity of fresh and processed orange juices. Different authors (Burdurlu, Koca, and Karadeniz 2006; Elsinghorst 
and Tikekar 2014) linked the degradation of AA with the formation of active compounds that could be responsible for the mutagenic effect, when fruits juices are treated with $\mathrm{UV}$ radiation. Therefore, it is interesting to analyze vitamin $\mathrm{C}$ degradation during UV processing.

The objectives of the present work were to investigate mutagenesis using the Ames test (1) in fresh squeezed orange juice, submitted to UV radiation doses required to achieve 5 and $10 \log _{10}$ reduction of different strains of the E. coli serotype O157:H7 at 4 and $20{ }^{\circ} \mathrm{C}$, and (2) in commercial pasteurized orange juice submitted to thermal treatment. S. Typhimurium TA98 and TA97a histidine-auxotrophic strains were used in the Ames test with and without metabolic activation (S9 mix). Additionally, the effect of UV radiation on AA degradation both in aqueous solution and in natural orange juice was analyzed.

\section{Materials and methods}

\subsection{Chemicals}

2-Nitrofluorene (2-NF, CAS 607-57-8), 2-aminofluorene (2-AF, CAS 153-78-6), sodium azide (CAS 26628-22-8), D-biotin (CAS 58-85-5), L-histidine.HCl (CAS 71-00-1), glucose-6-phosphate (CAS 56-73-5), and $\beta$-nicotin-amide-adenine dinucleotide phosphate (CAS 24292-60-2) were purchased from Sigma-Aldrich (Buenos Aires, Argentina). Nutrient broth $\mathrm{N}^{\circ} 2\left(\mathrm{NB} \mathrm{N}^{\circ} 2, \mathrm{CM} 0067\right)$ was purchased from Oxoid (Basingstoke, Hampshire, England), ampicillin (CAS 69-53-4), dimethyl sulfoxide (DMSO, CAS 67-68-5), and bacteriological agar type A (CAS 9002-18-0) were purchased from Merck (Darmstadt, Germany).

The post-microsomal fraction (S9) prepared from livers of Sprague-Dawley rats pretreated with a polychlorinated biphenyl mixture (Araclor 1254) was purchased from Molecular Toxicology Inc. (Boone, NC, USA).

\subsection{Sample preparation and physicochemical determinations in orange juice}

Freshly squeezed orange juice (without clarification) was obtained from fruits (Citrus sinensis var. Valencia) that were washed, brushed manually with sodium hypochlorite solution $(0.25 \mathrm{~g} / \mathrm{L})$, and rinsed with tap water. The fruits were cut and squeezed using a juice machine previously disinfected with $10 \%$ sodium hypochlorite solution and rinsed with distilled water. Commercial pasteurized orange juice packed in Tetra Pak was purchased at a local supermarket. This juice had been previously used as a thermally pasteurized model system (Oteiza et al. 2005) since it is free from preservatives.

The $\mathrm{pH}$ of juices was determined by using an electrode (model 50215, Hach, Loveland, $\mathrm{CO}, \mathrm{USA}$ ) and $\mathrm{pH}$ meter (model EC30, Hach, Loveland, CO, USA). Refractive index and soluble solids (Brix) were determined by an Abbé-type refractometer (Bellingham and Stanley, Kent, UK). All determinations were done in triplicate.

For determining the UV absorption coefficient of squeezed orange juice, different dilutions were prepared and absorbance at $254 \mathrm{~nm}$ was measured by using quartz cuvettes of $1 \mathrm{~cm}$ light path (Spectrophotometer DU 650, Beckman Coulter, Brea, CA, USA). The absorption coefficient was obtained by plotting absorbance vs. juice dilution (Oteiza et al. 2005). 


\subsection{UV treatment}

Low vapor pressure mercury lamps (Model 30W/G30 T8, Philips, Eindhoven, Netherlands) were used for UV-irradiation at $254 \mathrm{~nm}$ of the samples in a ventilated, temperature-controlled chamber with four UV lamps located at the top of the chamber, $15 \mathrm{~cm}$ above the samples. The samples were placed in a Lab-Line Environ-Shaker Model 3527 Orbital Incubator (Dubuque, IA, USA) at $220 \mathrm{rpm}$. UV fluence rate (E) or irradiance at $254 \mathrm{~nm}$ expressed in $\mathrm{mW} / \mathrm{cm}^{2}$, exposures times $(t)$, and fluence (UV dose or radiant exposure, $\mathrm{H}^{\prime}=\int \mathrm{E}^{\prime} \mathrm{dt}$ ), expressed in $\mathrm{J} / \mathrm{cm}^{2}$ (Koutchma et al. 2004), were measured at the sample position by using a digital UV radiometer (Model VLX-3 W CE, Vilber Lourmat, Torcy, France).

Aliquots of $5.7 \mathrm{~mL}$ orange juice were placed in sterile $9 \mathrm{~cm}$ diameter Petri dishes, yielding a layer of $0.9 \mathrm{~mm}$ thickness. The juice was subjected to UV fluence rates of 3.3 and 4.8 $\mathrm{mW} / \mathrm{cm}^{2}$, resulting in UV radiation doses of 1.5 and $3.0 \mathrm{~J} / \mathrm{cm}^{2}$ at 4 (in a cold chamber) and $20{ }^{\circ} \mathrm{C}$. These radiation doses corresponded to $5 \log _{10}$ (UVD5log) and $10 \log _{10}$ (UVD10log) reductions of E. coli serotype O157:H7 EDL 933, respectively (Oteiza et al. 2005).

\subsection{Effect of UV-irradiation on $A A$}

An aqueous solution of AA was prepared by dissolving $0.4 \mathrm{~g} \mathrm{AA}$ in $1 \mathrm{~L}$ distilled water. Aliquots of the solution were placed in $9 \mathrm{~cm}$ in diameter Petri dishes, yielding a layer thickness of $0.9 \mathrm{~mm}$. The samples were UV-irradiated at $20^{\circ} \mathrm{C}$ under shaking $(220 \mathrm{rpm})$ for exposure times ranging between 10 and $40 \mathrm{~min}$. With fresh squeezed orange juice, the experiments were performed under identical conditions. All UV exposure experiments were performed in duplicate.

The irradiated orange juice $(5 \mathrm{~mL})$ was paper-filtered (Whatman $\left.\mathrm{N}^{\circ} 1\right)$ and centrifuged at $11,000 \mathrm{rpm}$. The supernatant was filtered sequentially through 0.80 and $0.45 \mu \mathrm{m} \mathrm{mem-}$ brane filters (Osmonics Inc, Minnetonka, MN, USA).

The concentrations of AA were determined by HPLC (Waters 600E, Millipore Corp) with AMINEX HPX-87H column (BioRad Labs, Hercules, CA, USA) and UV Photodiode Array detector (Waters 996, Millipore Corporation), using $4.5 \mathrm{mmol} / \mathrm{L} \mathrm{H}_{2} \mathrm{SO}_{4}$ as mobile phase, flow rate $0.7 \mathrm{~mL} / \mathrm{min}$, at a temperature between 58 and $62{ }^{\circ} \mathrm{C}$. Absorption at $254 \mathrm{~nm}$ was recorded by measuring the peak corresponding to AA. Standard solutions of different concentrations $(0.050-1.5 \mathrm{~g} / \mathrm{L})$ were prepared for calibration.

\subsection{Mutagenesis assay}

The Ames test was performed as described by Maron and Ames (1983); Mortelmans and Zeiger (2000). S. Typhimurium strains TA98 and TA97a were obtained from Molecular Toxicology Inc. (Moltox, Boone, NC, USA). Stock bacteria were stored at $-80^{\circ} \mathrm{C}$ in $1 \mathrm{~mL}$ NB N 2 supplemented with $90 \mu \mathrm{L}$ DMSO. The tester strains genotype and $\mathrm{His}^{-}$requirement were confirmed as reported by Maron and Ames (1983).

In each experiment, UV non-irrradiated control samples were included as negative control. As positive control, the diagnostic mutagens 2-NF ( $2.5 \mu \mathrm{g} / \mathrm{plate})$ using the TA98 strain without metabolic activation, and 2-AF $(10 \mu \mathrm{g} /$ plate $)$ with TA98 and TA97a with 
metabolic activation were routinely included to confirm the reversion properties and specificity of each strain and the efficacy of the S9 mix. Negative and positive controls were incubated in parallel. The toxicity of the samples was checked by direct observation of the total bacterial background lawn, grown on selective plates until histidine traces were consumed (Verschaeve and Van Staden 2008).

Mutagenesis of commercial pasteurized orange juice packed in Tetra Pak was also tested for comparison.

The number of $\mathrm{His}^{+}$revertants was compared to the negative control by its mutagenicity index (MI).

$$
\mathrm{MI}=\frac{\text { Number of } \mathrm{His}^{+} \text {revertants induced in the samples }}{\text { Number of } \mathrm{His}^{+} \text {revertants induced in the negative control }}
$$

Triplicate plates were set up and run in parallel for each experimental point and the complete experiment was repeated twice.

\subsection{Mutagenicity of orange juices}

Aliquots of $0.05 \mathrm{~mL}$ of freshly squeezed, UV-irradiated orange juice or $0.1 \mathrm{~mL}$ of commercial pasteurized orange juice, and $0.1 \mathrm{~mL}$ of overnight cultures of the tester strains (TA97a and TA98) were added to $2 \mathrm{~mL}$ molten top agar $(0.5 \mathrm{mmol} / \mathrm{L}-$ histidine $/ 0.5 \mathrm{mmol} / \mathrm{L}-$ biotine) and $0.5 \mathrm{~mL} \mathrm{S9}$ mix or $0.5 \mathrm{~mL}$ phosphate buffer, $0.1 \mathrm{~mol} / \mathrm{L}, \mathrm{pH} 7.4$. The mixture was poured onto minimal agar plates, which were incubated at $37{ }^{\circ} \mathrm{C}$ for $48 \mathrm{~h}$, and the $\mathrm{His}^{+}$colonies were counted.

\subsection{Statistical analysis}

For the evaluation of mutagenicity, a two-fold enhancement and a two-fold decrease were considered as statistically significant mutagenic efficacy of a test compound. The mutagenic effect was confirmed with the ANOVA and Student's " $t$ " test. The level of significance was $p<0.05$. For statistical analysis of AA content, the SYSTAT Inc. 1990 software, version 5.0, USA was used.

\section{Results}

\subsection{Physicochemical characterization of orange juice}

The characterization of the freshly squeezed orange juice produced the following results: $\mathrm{pH}=3.64 \pm 0.20$, refractive index $=1.38$, and soluble solids $=13.1$ Brix. Absorption coefficient was 0.6371 absorbance $(\mathrm{mL} \text { juice } / \mathrm{mL} \text { solution })^{-1}$. UV treatment did not change these values (Oteiza et al. 2005). Average $\mathrm{pH}$ value of the commercial orange juice was 3.53; refractive index $=1.35$; and soluble solids $=12.52$ Brix.

\subsection{Mutagenicity of orange juices}

With TA98 and TA97a strains without metabolic activation (S9 mix), neither toxicity nor mutagenicity was found in commercial pasteurized juice (Table 1). But with TA97a strain 
Table 1. Induction of $\mathrm{His}^{+}$revertants in S. Typhimurium TA98 and TA97a by commercial pasteurized orange juice without and with $\mathrm{S} 9 \mathrm{mix}$.

\begin{tabular}{|c|c|c|c|c|c|}
\hline \multirow[b]{3}{*}{ Strain } & \multicolumn{5}{|c|}{ Commercial pasteurized orange juice } \\
\hline & \multirow[b]{2}{*}{$(\mu \mathrm{L})$} & \multicolumn{2}{|c|}{$-\$ 9$} & \multicolumn{2}{|c|}{$+\$ 9$} \\
\hline & & $\mathrm{His}^{+}$ & $\overline{{ }^{\mathrm{b}} \mathrm{Ml}}$ & $\mathrm{His}^{+}$ & ${ }^{\mathrm{b}} \mathrm{Ml}$ \\
\hline \multirow[t]{2}{*}{ TA98 } & 0 & ${ }^{a} 22 \pm 9$ & & ${ }^{a} 32 \pm 1$ & \\
\hline & 100 & $25 \pm 1$ & 1.1 & $33 \pm 3$ & 1.0 \\
\hline \multirow[t]{2}{*}{ TA97a } & 0 & ${ }^{\mathrm{a}} 167 \pm 3$ & & ${ }^{a} 326 \pm 7$ & \\
\hline & 100 & $149 \pm 3$ & 0.9 & $\mathrm{C} * *$ & $\mathrm{~N} / \mathrm{D}$ \\
\hline $\begin{array}{l}{ }^{\mathrm{a}} \text { Spont } \\
{ }^{\mathrm{b}} \mathrm{Ml}, \mathrm{m} \\
{ }^{\mathrm{C} * *} \text { Toxi } \\
\text { vation } \\
{ }^{*} \mathrm{~A} \text { sign }\end{array}$ & $\begin{array}{l}\text { ints. } \\
\text { data. D } \\
\text { late (T } \\
\text { ce fror }\end{array}$ & $\begin{array}{l}\text { gens: 2-NF } \\
\text { ) with met } \\
\text { control gro }\end{array}$ & $\begin{array}{l}\text { ) } \mathrm{TA9} \\
\text { n. Nu }\end{array}$ & $\begin{array}{l}\text { trains), witl } \\
N=6\end{array}$ & acti- \\
\hline
\end{tabular}

in the presence of metabolic activation, a toxic effect appeared. To evaluate the possible masking of mutagenicity produced by the high sample volume per plate $(0.1 \mathrm{~mL} /$ plate $)$, dose-response assays using lower volumes $(5,10$, and $25 \mu \mathrm{L} /$ plate) were carried out (Table 2). The mutagenic index $\mathrm{MI} \geq 2$ indicates a clearly mutagenic effect induced by commercial pasteurized orange juice in strain TA97a with metabolic activation, the highest value being 9.45. A reproducible linear relationship of the dose-response assay was observed. However, by using larger volumes, the number of revertants decreased. This result was interpreted as a toxic effect due to high sample volume.

Light microscopy examination showed a reduced background lawn of the corresponding samples, confirming this interpretation.

Similar results about the dose-response curves were reported by Ekasari, Jongen, and Pilnik (1986) working with freshly pressed orange juice, heated up to $30 \mathrm{~min}$ at $93{ }^{\circ} \mathrm{C}$, and with commercial juices subjected to thermal treatments. These samples were assayed for mutagenesis by the Ames test with $S$. Typhimurium strain TA100, modified to include a $4 \mathrm{~h}$ pre-incubation time at $37^{\circ} \mathrm{C}$ and $\mathrm{pH}$ 7.4. These authors reported that the thermal treatment induced mutagenicity (attributed to Maillard intermediary products), which was dose related, achieving a maximum in the number of revertants and decreasing when the volume of the sample per plate increased.

In this work, different mutagenic effects were induced by UV radiation in fresh squeezed orange juice in the presence of TA98 and TA97a strains, with and without S9 mix. Fresh squeezed orange juice was neither toxic nor mutagenic without $S 9$ mix at the

Table 2. Effect of sample volume on the induction of $\mathrm{His}^{+}$revertants in S. Typhimurium TA97a by commercial pasteurized orange juice without and with metabolic activation (dose-response).

\begin{tabular}{|c|c|c|c|c|c|}
\hline \multirow[b]{3}{*}{ Strain } & \multicolumn{5}{|c|}{ Commercial pasteurized orange juice } \\
\hline & \multirow[b]{2}{*}{$(\mu L)$} & \multicolumn{2}{|c|}{$-\mathrm{S9}$} & \multicolumn{2}{|c|}{+59} \\
\hline & & $\mathrm{His}^{+}$ & $\overline{{ }^{\mathrm{b}} \mathrm{Ml}}$ & $\mathrm{His}^{+}$ & ${ }^{\mathrm{b}} \mathrm{Ml}$ \\
\hline \multirow[t]{4}{*}{ TA97a } & 0 & ${ }^{\mathrm{a}} 154 \pm 6$ & & $a_{325 \pm 69}$ & \\
\hline & 5 & $162 \pm 6$ & 1.1 & $3072 \pm 95^{*}$ & 9.5 \\
\hline & 10 & $141 \pm 5$ & 0.9 & $640 \pm 21$ & 2.0 \\
\hline & 25 & $161 \pm 1$ & 1.0 & $558 \pm 11$ & 1.7 \\
\hline
\end{tabular}

${ }^{\text {a}}$ Spontaneous revertants.

${ }^{\mathrm{b}} \mathrm{Ml}$, mutagenic index. Diagnostic mutagens: 2-NF (2.5 $\left.\mu \mathrm{g} / \mathrm{plate}\right)$ (TA98 and TA97a strains), without metabolic activation; $2-\mathrm{AF} 10 \mu \mathrm{g} /$ plate (TA98 and TA97a) with metabolic activation.

${ }^{*} A$ significant difference from the negative control group $(p<0.05)$. 
Table 3. Induction of $\mathrm{His}^{+}$revertants in S. Typhimurium T98 with and without metabolic activation, by fresh squeezed orange juice UV radiated under different radiation doses, fluence rate, and temperature. Orange juice volume $=50 \mu \mathrm{L} /$ plate.

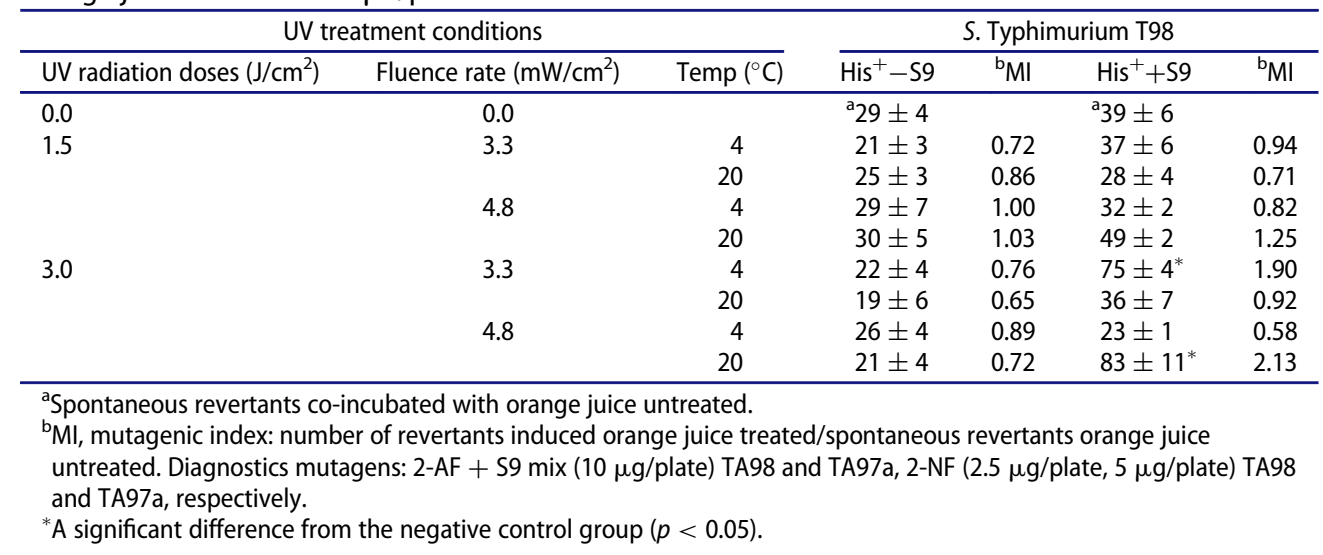

tested concentration of $0.050 \mathrm{~mL} /$ plate, under the assayed experimental conditions (Tables 3 and 4). With TA98 in the presence of S9 mix, the fresh squeezed orange juice exposed to UV radiation doses of $3.0 \mathrm{~J} / \mathrm{cm}^{2}$ (fluence rates $=4.8 \mathrm{~mW} / \mathrm{cm}^{2}\left(20{ }^{\circ} \mathrm{C}\right.$ ) ) presented a weak mutagenic effect (borderline), with $\mathrm{MI}=2.13(p<0.05)$ (Table 3$)$.

When the TA97a strain was used in the presence of S9 mix, the fresh squeezed orange juice treated with UV radiation dose of $3.0 \mathrm{~J} / \mathrm{cm}^{2}$ and fluence rate $=4.8 \mathrm{~mW} / \mathrm{cm}^{2}$ at 20 ${ }^{\circ} \mathrm{C}$ showed a stronger mutagenic effect $(\mathrm{MI}=9.01)$ (Table 4$)$.

\subsection{Effect of UV on AA degradation}

The stability of vitamin C was studied in this work since different authors, such as Burdurlu, Koca, and Karadeniz (2006), Elsinghorst and Tikekar (2014), linked the degradation of AA with the probable formation of active compounds that could be responsible for the mutagenic effect when fruits juices are treated with UV radiation. Squeezed orange

Table 4. Induction of $\mathrm{His}^{+}$revertants in S. Typhimurium T97a with and without metabolic activation, by fresh squeezed orange juice UV radiated under different conditions of radiation doses, fluence rate, and temperature. Orange juice volume $=50 \mu \mathrm{L} /$ plate.

\begin{tabular}{|c|c|c|c|c|c|c|}
\hline \multicolumn{3}{|c|}{ UV treatment conditions } & \multicolumn{4}{|c|}{ S. Typhimurium T97a } \\
\hline UV radiation doses $\left(\mathrm{J} / \mathrm{cm}^{2}\right)$ & Fluence rate $\left(\mathrm{mW} / \mathrm{cm}^{2}\right)$ & $\operatorname{Temp}\left({ }^{\circ} \mathrm{C}\right)$ & $\mathrm{His}^{+}-\mathrm{S9}$ & ${ }^{\mathrm{b}} \mathrm{Ml}$ & $\mathrm{His}^{+}+\mathrm{S} 9$ & ${ }^{\mathrm{b}} \mathrm{Ml}$ \\
\hline 0.0 & 0.0 & & ${ }^{\mathrm{a}} 108 \pm 1$ & & $a_{148 \pm 2}$ & \\
\hline \multirow[t]{4}{*}{1.5} & 3.3 & 4 & $118 \pm 1$ & 1.09 & $123 \pm 2$ & 0.83 \\
\hline & & 20 & $100 \pm 3$ & 0.92 & $103 \pm 3$ & 0.69 \\
\hline & 4.8 & 4 & $153 \pm 1$ & 1.42 & $118 \pm 2$ & 1.0 \\
\hline & & 20 & $107 \pm 2$ & 0.99 & $185 \pm 9$ & 1.25 \\
\hline \multirow[t]{4}{*}{3.0} & 3.3 & 4 & $97 \pm 2$ & 0.89 & $113 \pm 3$ & 0.76 \\
\hline & & 20 & $101 \pm 2$ & 0.93 & $105 \pm 6$ & 0.71 \\
\hline & 4.8 & 4 & $116 \pm 1$ & 1.07 & $173 \pm 3$ & 1.17 \\
\hline & & 20 & $125 \pm 2$ & 1.16 & $1334 \pm 346 *$ & 9.01 \\
\hline
\end{tabular}

\footnotetext{
${ }^{\mathrm{a}}$ Spontaneous revertants co-incubated with orange juice untreated.

${ }^{\mathrm{b}} \mathrm{Ml}$, mutagenic index: number of revertants induced orange juice treated/spontaneous revertants orange juice untreated. Diagnostics mutagens: 2-AF + S9 mix (10 $\mu \mathrm{g} /$ plate) TA98 and TA97a, 2-NF ( $2.5 \mu \mathrm{g} /$ plate, $5 \mu \mathrm{g} /$ plate) TA98 and TA97a, respectively. ${ }^{*}$ s significant difference from the negative control group $(p<0.05)$.
} 


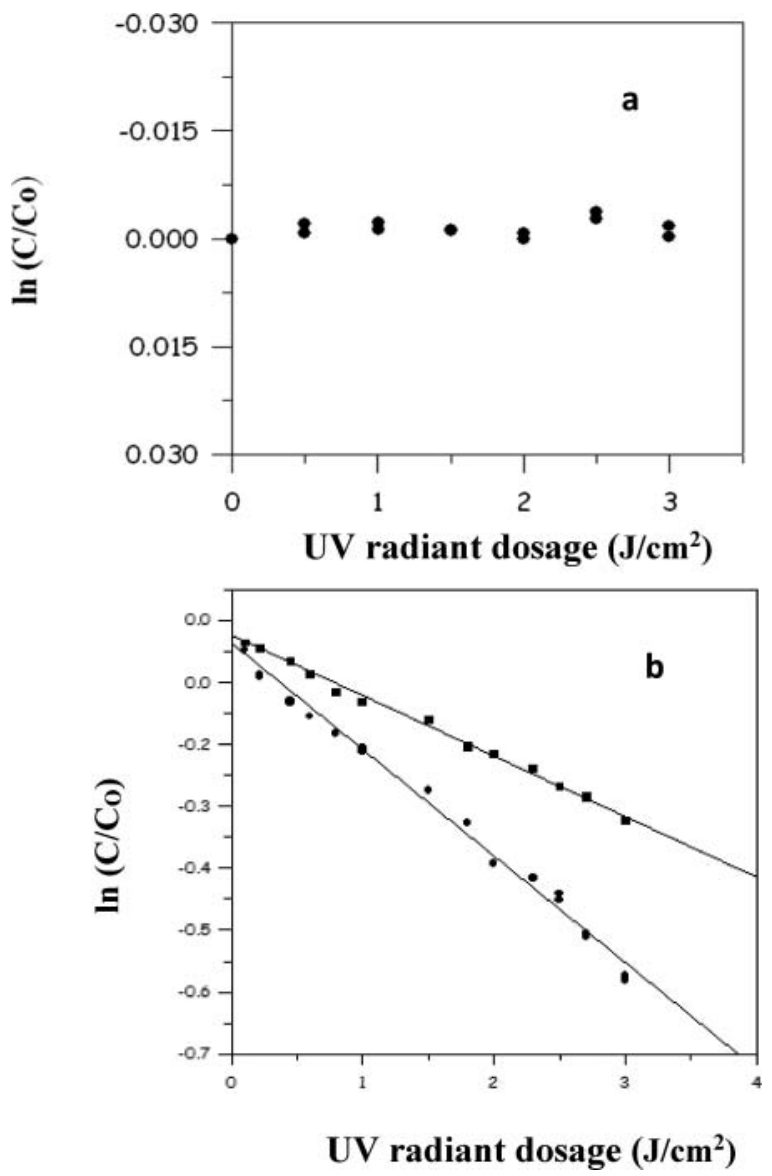

Figure 1. Effect of different UV radiation doses (between 0 and $3.0 \mathrm{~J} / \mathrm{cm}^{2}$ ) using $3.3 \mathrm{~mW} / \mathrm{cm}^{2}$ on the stability of ascorbic acid: (a) in aqueous solution at $20^{\circ} \mathrm{C}$ (b) in squeezed orange juice UV irradiated at $20^{\circ} \mathrm{C}$ (circle); UV irradiated at $4{ }^{\circ} \mathrm{C}$ (square).

juice is characterized for its high content in vitamin $\mathrm{C}$ (or AA) which varies between 0.37 and $0.55 \mathrm{~g} / \mathrm{L}$ of juice, depending on orange variety and the time of the year (Zerdin, Rooney, and Vermuë 2003).

Results about stability of AA at $20^{\circ} \mathrm{C}$ in: (1) aqueous solutions subjected to UV radiation doses ranging between 0 and $3.0 \mathrm{~J} / \mathrm{cm}^{2}$ (using fluence rates of 3.3 and $4.8 \mathrm{~mW} / \mathrm{cm}^{2}$ ), and in (2) squeezed orange juice UV radiated at 20 and $4{ }^{\circ} \mathrm{C}$, are shown in Figure $1(\mathrm{a}, \mathrm{b})$.

$\mathrm{UV}$ radiation (using a fluence rate of $3.3 \mathrm{~mW} / \mathrm{cm}^{2}$ at $20{ }^{\circ} \mathrm{C}$ ) did not affect the stability of AA in aqueous solution (Figure 1(a)), but degradation of AA was observed (Figure 1(b)) when the treatment was performed on squeezed orange juice, following a first order equation (Equation 1).

$$
\ln \left(\frac{\mathrm{C}}{\mathrm{CO}}\right)=-k \mathrm{H}^{\prime}
$$

where $\mathrm{H}^{\prime}=\mathrm{UV}$ radiation dose $\left(\mathrm{J} / \mathrm{cm}^{2}\right)$ and $k$ is the coefficient that accounts for AA degradation $\left(\mathrm{J} / \mathrm{cm}^{2}\right)^{-1}$. 
Experimental data were satisfactorily fitted by Equation (1) with $r^{2}$ values ranging between 0.992 and 0.995 . The decrease in the content of AA as a function of the UV radiation dose was more marked at $20^{\circ} \mathrm{C}$ than under refrigerated conditions $\left(4{ }^{\circ} \mathrm{C}\right)$.

Considering the observed stability of AA in UV-treated aqueous solutions, it can be assumed that UV may affect enzymatic and/or chemical systems present in orange juice that would be responsible for AA degradation.

Tikekar, Anantheswaran, and La Borde (2011) also demonstrated that UV radiation induced degradation of AA in apple juice using a collimated beam batch UV reactor. They reported that AA degradation occurred more rapidly at higher UV radiation doses. Degradation rates were also greater at higher values of $\mathrm{pH}$ and higher malic acid and fructose concentrations.

The results obtained in this work are in agreement with Tran and Farid (2004) who studied the effect of UV on vitamin $\mathrm{C}$ in orange juice thin film reactor and reported that AA in reconstituted orange juice was degraded as UV radiation doses increased, following a first order kinetics.

\section{Discussion}

Since the Ames test is a reversion mutagenicity assay, the bacterial tester strain response is dependent on the point mutation which generates the histidine-auxotrophic condition. Accordingly, the strain response is conditioned not only by the mutagenic potency of the active compound but also by its mutational specificity. It has been shown that the $(-1)$ frameshift mutation hisD3052 in TA98 strain genetic background can be reverted also by a complex frameshift mutation (frameshift mutation plus a flanking or nearby base pair substitution). The complex mutation also requires the presence of molecular side groups capable of forming adducts with DNA (mostly C-8-Guanine). This effect is induced by aromatic amines in the presence of metabolic activation (S9 mix) (Levine, Schaaper, and De Marini 1994) and the frameshift mutation depends on planar molecular moiety of the active compound which enables its intercalation into the DNA (Rodriguez et al. 2010). On the other hand, TA97a strain also requires a frameshift mutagen to revert mutation, such as intercalating agents (Levin et al. 1982). Then the differences found in the response are dependent on the selected indicator bacteria, where strain TA97a seems to be more sensitive for the detection of particular active agents. In both pasteurized and UV-treated juices, the mutagenic activity was detected in the presence of metabolic activation indicating the indirect mutagenic activity for this strain. Because bacteria are unable to metabolize chemicals via cytochromes $\mathrm{P} 450$, as in mammals and other vertebrates, the inclusion of an exogenous mammalian metabolic activation system (S9) was a key component for making the bacterial mutagenicity test useful.

Citrus constitutes the unique significant source of dietary flavanones, a subclass of flavonoids. Hesperidin (hesperetin-7-O-rutinoside) represents more than $90 \%$ of the flavanones found in orange and orange juice (Neveu et al. 2010; Perche et al. 2014). Orange contains quercetin (a plant-derived flavonoid) in concentrations ranging between 3.4 to $5.7 \mathrm{mg} / \mathrm{L}$ (Hertog, Hollman, and van de Putte 1993).

Bjeldanes and Chang (1977) provided information related to the mutagenic activities of several flavonoids and flavonoid metabolites that were examined by means of $S$. Typhimurium. Among the tested compounds (naringin, rutin, neohesperetin, hesperetin, 
dihydroquercetin, quercetin, quercetin penta-acetate, permethylquercetin, m-hydroxyphenylacetic acid and m, p-dihydroxyphenylacetic acid), these authors reported that only quercetin was mutagenic without microsomal activation. With activation, however, the mutagenic activity of quercetin increased significantly and that of quercetin penta-acetate was observed.

Nagao et al. (1981) analyzed the mutagenicity of different flavonoids using the Ames test, with S. Typhimurium TA98 and TA100, and reported that quercetin was the strongest mutagen. Resende et al. (2012) reported a study of mutagenicity of flavonoids assayed by Ames test, in TA98, TA100, and TA102 S. Typhimurium strains. In the presence of S9 mix, kaempferol and galangin were mutagenic in the TA98 strain and kaempferol showed signs of mutagenicity in the other strains in the absence of S9 mix. Quercetin was the only mutagenic flavonoid with a mutagenic index higher than 2.0 at the concentration of $24.5 \mathrm{nmol} / \mathrm{plate}$ in strain TA98 (Resende et al. 2012). However, Nijveldt et al. (2001) reported that there is much controversy regarding the toxic or even mutagenic properties of quercetin.

Ekasari, Jongen, and Pilnik (1986) used Ames test and commented that freshly pressed orange juice had no mutagenic properties and that mutagenicity was induced by heat treatment $\left(30 \mathrm{~min}\right.$ at $\left.93^{\circ} \mathrm{C}\right)$ using $200 \mu \mathrm{L}$ per plate in TA100 tester strain. The mutagenic response was attributed to Maillard intermediary products as the heat treatments were mild and not sufficient to produce brown pigments. Ekasari et al. (1990) carried out the partial characterization of mutagenic compounds in heated orange juice and concluded that they are polar, nonvolatile, carry no charge, and have molecular weights $<700$ daltons.

Friedman, Wilson, and Ziderman (1990) investigated mutagenic response on fresh and heated orange juice using $1000 \mu \mathrm{L}$ per plate, with Ames tester strains $S$. Thyphimurium TA 98, TA 100, TA 102, and TA 2637. However, their results did not agree with the increase in mutagenicity reported by Ekasari, Jongen, and Pilnik (1986) in thermally treated juices. Ekasari et al. (1993) worked with heated orange juice $\left(93{ }^{\circ} \mathrm{C}, 2 \mathrm{~min}\right)$ and, after submitting to Salmonella/mutagenicity assay, elucidated the molecular weight and chemical structure of the mutagenic agents. They consisted of several compounds with molecular weights of 162, 180, 254, 288, 342, 360, and 540 daltons. Franke et al. (2004) studied the mutagenic effects of in natura and processed (fresh and frozen) orange juices using 100, 500, and $2000 \mu \mathrm{L}$ per plate in the Ames test. These authors reported that the highest responses were observed in strains TA97a and TA98, in agreement with the results obtained in this work. Moreover, they concluded that fresh processed juice, which had the highest antioxidant potential, was not mutagenic in any of the tested strains. Positive results for mutagenesis in TA97a with metabolic activation were correlated with total phenolic compounds and vitamin $\mathrm{C}$.

Surh and Tannenbaum (1994) studied one of the major intermediate products in the Maillard reaction 5-(hydroxymethyl) furfural (HMF) that is present in a wide variety of foods. This aldehyde is formed as a decomposition product of glucose and fructose in foodstuffs subjected to cooking or heat sterilization and it has been found to possess mutagenic and DNA strand-breaking activity. HMF is present in high concentrations in many foods, sometimes exceeding $1 \mathrm{~g} / \mathrm{kg}$ in certain dried fruits and caramel products (Janzowski et al. 2000). The presence of mutagens such as furan or the furan metabolite cis-2-butene-1,4-dial, reactive aldehydes thought to be the ultimate carcinogen, was 
reported by several authors (Chen, Hecht, and Peterson 1997; Fan and Geveke 2007; Koutchma, Forney, and Moraru 2009; Vranová and Ciesarová 2009; Bule et al. 2010; Elsinghorst and Tikekar 2014; Peterson, Naruko, and Predecki 2000; Byrns et al. 2006; Kellert et al. 2008).

The US FDA found that furan is present in many thermally processed foods, with furan levels of $\approx 100 \mathrm{ppb}$ in some of the foods (FDA, 2004).

Vranová and Ciesarová (2009) reported that literature data indicate multiple sources of furan formation originating from (1) thermal degradation/Maillard reaction reducing sugars, alone or in the presence of amino acids, (2) thermal degradation of certain amino acids, and thermal oxidation of (3) AA, (4) poly-unsaturated fatty acids and (5) carotenoids.

With reference to UV treatment in juices, Fan and Geveke (2007) investigated whether $\mathrm{UV}-\mathrm{C}$ induced furan in apple cider and its components and they determined furan levels in apple cider exposed to UV-C at doses that would inactivate E. coli by 5-log, considering that the major source of furan was apparently fructose. These authors observed that UV-C treatment (at incident doses up to $9 \mathrm{~J} / \mathrm{cm}^{2}$ ) of fructose solutions produced a higher amount of furan, while very low concentrations of furan were induced by UV-C in glucose or sucrose solutions and virtually no furan was induced by UV-C from solutions of AA or malic acid.

Similarly, Bule et al. (2010) reported that furan is a suspected human carcinogen that is produced by thermal or UV-C treatment of various foods, such as fruit juices. Studies performed on individual components of fruit juices revealed fructose to be the main constituent in fruit juices that is responsible for furan formation during UV treatment. However, glucose does not support furan formation upon UV exposure.

Elsinghorst and Tikekar (2014) demonstrated that fructose has shown a significant reactivity during UV processing of fruit juices that can adversely affect product quality. This reactivity of fructose was attributed to the oxidative nature of the products formed from UV induced photolysis of fructose. They proved that the transient oxidative species, including free radicals and not one of the final photolysis products such as furan, are responsible for UV photolysis of fructose.

\section{Conclusions}

Applied UV radiation did not affect the stability of AA in aqueous solution. However, degradation of AA was observed when the treatment was performed on squeezed orange juice, following a first order kinetics.

In commercial pasteurized orange juice (submitted to thermal treatment), mutagenesis was not observed in the absence of metabolic activation in any of the strains used (TA98 and TA97a). A high mutagenic effect was observed using TA97a (a strain that detects frameshift mutation) in the presence of metabolic activation. A very high value of mutagenic index was obtained when low volumes per plate of orange juice were used in the Ames test $(<25 \mu \mathrm{L})$. However, when larger volumes were used, the number of revertants decreased, indicating a toxic effect.

Fresh squeezed orange juice exposed to UV radiation doses required to achieve $10 \log _{10}$ reductions of different strains of Escherichia coli serotype O157:H7 showed, in the 
presence of metabolic activation, a borderline mutagenic effect with TA98 strain and a strong mutagenic effect with TA97a, both strains inducing frameshift mutation.

It can be concluded that the requirement of metabolic activation to detect mutagenic effect can be attributed to the presence of compounds capable of generating reactive species, including free radicals and metabolites that react covalently with DNA.

\section{Acknowledgments}

The authors acknowledge the financial support of Universidad Nacional de La Plata, Consejo Nacional de Investigaciones Científicas y Técnicas (CONICET) and Agencia Nacional de Promoción Científica y Tecnológica (ANPCYT) in Argentina.

\section{Disclosure statement}

No potential conflict of interest was reported by the authors.

\section{Funding}

Universidad Nacional de La Plata [Project I-206], Consejo Nacional de Investigaciones Cientificas y Tecnicas (CONICET), Argentina; Agencia Nacional de Promocióon Cientifica y Tecnológica (ANPCYT), Argentina [Project PICT 2006- Nro 00708].

\section{ORCID}

Noemi Zaritzky (D) http://orcid.org/0000-0002-6814-1112

\section{References}

Aneja, K.R., R. Dhiman, N.K. Aggarwal, and A. Aneja. 2014. "Emerging Preservation Techniques for Controlling Spoilage and Pathogenic Microorganisms in Fruit Juices." International Journal of Microbiology Article ID 758942, 14.

Basaran, N., A. Quintero-Ramos, M.M. Moake, J.J. Churey, and R.W. Worobo. 2004. "Influence of Apple Cultivars on Inactivation of Different Strains of Escherichia coli O157:H7 in Apple Cider by UV Irradiation." Applied and Environmental Microbiology 70: 6061-6065.

Bjeldanes, L.F., and G.W. Chang. 1977. "Mutagenic Activity of Quercetin and Related Compounds." Science 197: 577-578.

Bule, M.V., K.M. Desai, B. Parisi, S.J. Parulekar, P. Slade, R.S. Singhal, and A. Rodriguez. 2010. "Furan Formation During UV-Treatment of Fruit Juices." Food Chemistry 122: 937-942.

Burdurlu, H.S., N. Koca, and F. Karadeniz. 2006. "Degradation of Vitamin C in Citrus Juice Concentrates Curing Storage." Journal of Food Engineering 74: 211-216.

Byrns, M.C, C.V. Choua, J.W. Neidigh, J.L. Abad, R.A. Jones, and L.A. Peterson. 2006. "Detection of DNA Adducts Derived from the Reactive Metabolite of Furan, cis-2-Butene-1,4-dial." Chemical Research in Toxicology 19: 414-420.

Chen, L.J., S.S. Hecht, and L.A. Peterson. 1997. "Characterization of Amino Acid and Glutathione Adducts of cis-2-Butene-1,4-dial, a Reactive Metabolite of Furan." Chemical Research Toxicology 10: $866-874$.

Choi, L., and S.S. Nielsen. 2005. "The Effects of Thermal and Nonthermal Processing Methods on Apple Cider Quality and Consumer Acceptability.” Journal of Food Quality 28: 13-21.

Choudhary, R., and S. Bandla. 2012. "Ultraviolet Pasteurization for Food Industry." International Journal of Food Science and Nutrition Engineering 2: 12-15. 
Ekasari, I., W.M.F. Jongen, and W. Pilnik. 1986. "Use of Bacterial Mutagenicity Assay as a Rapid Method for the Detection of Early Stage of Maillard Reaction in Orange Juices." Food Chemistry 21: $125-131$.

Ekasari, I., H.E. Berg, W.M.F. Jongen, and W. Pilnik. 1990. "Characterization of Mutagenic Compound(s) in Heated Orange Juice." Food Chemistry 36: 11-18.

Ekasari, I., R.H. Fokkens, M.H. Bonestroo, H.A. Schols, N.M.M. Nibbering, and W. Pilnik. 1993. "Characterization of Mutagenic Compounds in Heated Orange Juice by UV and Mass Spectra." Food Chemistry 46: 77-79.

Elsinghorst, A., and R.V. Tikekar. 2014. "Generation of Oxidative Species from Ultraviolet Light Induced Photolysis of Fructose.” Food Chemistry 154: 276-281.

Fan, X., and D. Geveke. 2007. "Furan Formation in Sugar Solution and Apple Cider upon Ultraviolet Treatment." Journal of Agricultural and Food Chemistry 55: 7816-7821.

FDA (Food and Drug Administration). 2004. "Furan in Food." Thermal treatment, request for data and information. Accessed 10.06.15. http://www.fda.gov/OHRMS/DOCKETS/98fr/04n-0205nrd0001.pdf. Exploratory data on furan in food data.

FDA (Food and Drug Administration). 2013. "Kinetics of Microbial Inactivation for Alternative Food Processing Technologies Ultraviolet Light.” Page Last Updated: 04/10/2013. http://www. fda.gov/Food/FoodScienceResearch/SafePracticesforFoodProcesses/ucm103137.htm

Franke, S.I.R., K. Ckless, J.D. Silveira, G. Rubensam, M. Brendel, B. Erdtmann, and J.A.P. Henriques. 2004. "Study of Antioxidant and Mutagenic Activity of Different Orange Juices." Food Chemistry 88: 45-55.

Friedman, M., R.E. Wilson, and I.I. Ziderman. 1990. "Effect of Heating on Mutagenicity of Fruit Juices in the Ames Test." Journal of Agricultural and Food Chemistry 38: 740-743.

Hanes, D.E., R.W. Worobo, P.A. Orlandi, D.H. Burr, M.D. Miliotis, M.G. Robi, J.W. Bier, J. Arrowood, J.J. Churey, and G.J. Jackson. 2002. "Inactivation of Cryptosporidium parvum Oocysts in Fresh Apple Cider Using Ultraviolet Irradiation." Journal of Applied and Environmental Microbiology 68: 4168-4172.

Hertog, M.G., P.C.H. Hollman, and B. van de Putte. 1993. "Content of Potentially Anticarcinogenic Favonoids of Tea Infusions, Wines, and Fruit Juices." Journal of Agricultural Food Chemistry 41: $1242-1246$.

JanzowskI, C., V. Glaab, E. Samimi, J. Schlatter, and G. Eisenbrand. 2000. “5-Hydroxymethylfurfural: Assessment of Mutagenicity. DNA-damaging Potential and Reactivity Towards Cellular Glutathione." Food and Chemical Toxicology 38: 801-809.

Koutchma, T., S.S. Keller, S.S. Chirtel, and B. Parisi. 2004. "Ultraviolet Disinfection of Juice Products in Laminar and Turbulent Flow Reactors." Innovative Food Science and Emerging Technologies 5: 179-189.

Koutchma, T., L.J. Forney, and C.I. Moraru. 2009. "UV Processing Effect on Quality of Foods.” In: Ultraviolet Light in Food Technology: Principles and Applications, edited by T. Koutchma, L.J. Forney, and C.I. Moraru, 103-105. Boca Raton, FL: CRC Press.

Kellert, M., A. Brink, I. Richter, J. Schlatter, and W.K. Lutz. 2008. "Tests for Genotoxicity and Mutagenicity of Furan and its Metabolite cis-2-Butene-1,4-dial in L5178Y tk+/- Mouse Lymphoma Cells." Mutation Research 657: 127-132.

Levin, D.E., M.C. Hollstein, M.F. Chritman, E.A. Schwiers, and B.N. Ames. 1982. "A New Salmonella Tester Strain (TA102) with A: T Base Pairs at the Sites of Mutation Detects Oxidative Mutagens." Proceedings of the National Academy of Sciences USA 79: 7445-7449.

Levine, J.G., R.M. Schaaper, and D.M. De Marini. 1994. "Complex Review of the Biology of Quercetin and Related Bioflavonoid." Frameshift Mutations Mediated by Plasmid pKM101: Mutational Mechanisms Deduced from 4-Aminobiphenyl-Induced Mutation Spectra in Salmonella." Genetics 136: 731-746.

López-Gomez, A., M. Ros-Chumillas, and Y.Y. Belisario-Sánches. 2010. "Packaging and the Shelf Life of Orange Juice.” In Food Packaging and Shelf Life: A Practical Guide, edited by G. L. Robertson, 179-189. Boca Raton, FL: CRC Press.

Maron, D.M., and B.N. Ames. 1983. "Revised Methods for the Salmonella Mutagenicity Test." Mutation Research 113: 173-215. 
Mazaki, M., T. Ishii and M. Uyeta. 1982. "Mutagenicity of Hydrolysates of Citrus Fruit Juices." Mutation Research 101: 283-291.

Miller, R.W., W. Jeffrey, D. Mitchell, and M. Elasri. 1999. "Bacterial Responses to Ultraviolet Light." American Society of Microbiology News 65: 535-541.

Mortelmans, K., and E. Zeiger. 2000. “The Samonella/Microsome Mutagenicity Assay.” Mutation Research 455: 29-60.

Nagao M., N. Morita, J. Yahagi, M. Shimizu, M. Kuroyanagi, M. Fukuoda, K. Yoshihira, S. Natori, T. Fujino, and T. Sugimura. 1981. "Mutagenicities of 61 Flavonoids and 11 Related Compounds." Environmental and Molecular Mutagenesis 3: 401-419.

Neveu, V., J. Perez-Jimenez, F. Vos, V. Crespy, L. du Chaffaut, L. Mennen, C. Knox, et al. 2010. "Phenol-Explorer: An Online Comprehensive Database on Polyphenol Contents in Foods." The Journal of Biological Data Base Sand Curation. http://www.ncbi.nlm.nih.gov/pmc/articles/ PMC2860900/

Nijveldt R.J., E. van Nood, D.E. van Hoorn, P.G. Boelens, K. van Norren, and P.A. van Leeuwen. 2001. "Flavonoids: A Review of Probable Mechanisms of Action and Potential Applications." American Journal of Clinical Nutrition 74: 418-425.

Oteiza, J.M., M. Peltzer, L. Giannuzzi, and N. Zaritzky. 2005. “Antimicrobial Efficacy of UV Radiation on Escherichia coli O157:H7 in Fruit Juices of Different Absorptivities." Journal of Food Protection 68: 49-58.

Oteiza, J.M., L. Giannuzzi, and N. Zaritzky. 2010. "Ultraviolet Treatment of Orange Juice to Inactivate E. coli O157:H7 as Affected by Native Micro flora." Food Bioprocess Technology 3: 603-614.

Peterson, L.A., K.C. Naruko, and D.P. Predecki. 2000. "A Reactive Metabolite of Furan, cis-2Butene-1,4-dial, is Mutagenic in the Ames Assay." Chemical Research in Toxicology 13: 531-534.

Perche, O., J. Vergnaud-Gauduchon, C. Morand, C. Dubray, A. Mazur, and M.P. Vasson. 2014. "Orange Juice and its Major Polyphenol Hesperidin Consumption do not Induce Immunomodulation in Healthy Well-nourished Humans." Clinical Nutrition 33: 130-135.

Resende, F.A., W. Vilegas, L.C. dos Santos, and E.A. Varanda. 2012. "Mutagenicity of Flavonoids Assayed by Bacterial Reverse Mutation (Ames) Test." Molecules 17: 5255-5268.

Reyns, K.M.F.A., A.M.J. Diels, and C.W. Michiels. 2004. "Generation of Bactericidal and Mutagenic Components by Pulsed Electric Field Treatment." International Journal of Food Microbiology 93: 165-173.

Rodriguez, M.M., L. Giannuzzi, M. Reta, and M.L. Larramendy. 2010. “The Antimutagenic Capacity of the Aqueous Extract of Baccharis articulata (Lam.) Persoon." Toxicological and Environmental Chemistry 93: 251-260.

Rupasinghe H.P.V., and L.J. Yu. 2012. "Emerging Preservation Methods for Fruit Juices and Beverages." In Food Additive, edited by Y. El-Samragy. InTech http://cdn.intechweb.org/pdfs/28909.pdf

Sastry, S.K., A.K. Datta, and R.W. Worobo. 2000. "Ultraviolet Light." Journal of Food Science 65: $90-92$.

Surh, Y.J., and S.R. Tannenbaum. 1994. "Activation of the Maillard Reaction Product 5-(Hydroxymethyl)furfural to Strong Mutagens via Allylic Sulfonation and Chlorination." Chemical Research in Toxicology 7: 313-318.

Tandon, K., R.W. Worobo, J.J. Churey, and O.I Padilla-ZaKour. 2003. "Storage Quality of Pasteurized and UV Treated Apple Cider Preservation." Journal of Food Processing and Preservation 27: $21-35$.

Tikekar, R.V., C. Anantheswaran, and L.F. La Borde. 2011. "Ascorbic Acid Degradation in a Model Apple Juice System and in Apple Juice During Ultraviolet Processing and Storage.” Journal Food Science 76: 62-71.

Torkamani, A.E., and M. Niakousari. 2011. "Impact of UV-C Light on Orange Quality and Shelf Life." International Journal of Food Research 18: 1265-1268.

Tran, M.T.T., and M. Farid. 2004. "Ultraviolet Treatment of Orange Juice." Innovative Food Science and Emerging Technologies 5: 495-502.

USDA (United States of Department of Agriculture). 2016. "Citrus: World Markets and Trade." United States Department of Agriculture Foreign Agricultural Service/USDA. Office of Global 
Analysis. Accessed March 11 2016. http://www.fas.usda.gov/data/citrus-world-markets-andtrade

Verschaeve, L., and J. Van Staden. 2008. "Mutagenic and Antimutagenic Properties of Extracts from South African Traditional Medicinal Plants." Journal Ethnopharmacology 119: 575-587.

Vranová, J., and Z. Ciesarová. 2009. "Furan in Food - a Review." Czech Journal Food Science 27: $1-10$.

Wright, J.R., S.S. Sumner, C.R. Hackney, M.D. Pierson, and B.W. Zoecklein. 2000. "Efficacy of Ultraviolet Light for Reducing Escherichia coli O157:H7 in Unpasteurized Apple Cider.” Journal of Food Protection 63: 563-567.

Zerdin K., M.L. Rooney, and J. Vermuë. 2003. “The Vitamin C Content of Orange Juice Packed in an Oxygen Scavenger Material.” Food Chemistry 82: 387-395. 